\title{
Who's in Charge Now? The Decision Autonomy of Hotel General Managers
}

Cornell Hospitality Quarterly

20I4, Vol. 55(4) 433-447

(C) The Author(s) 2014

Reprints and permissions:

sagepub.com/journalsPermissions.nav DOI: $10.1177 / 1938965513518839$

cqx.sagepub.com

(S)AGE

\author{
Demian Hodari' and Michael C. Sturman ${ }^{2}$
}

\begin{abstract}
The general manager (GM) is the key position in a hotel, but the changing structure of the industry has altered the scope of the GM's decision-making autonomy. In many hotels, the GM is an employee of a hotel operating firm and is effectively an agent of the operator or owner (and sometimes both parties). These principals have authority over several aspects of hotel operation, although the GM also has responsibility. A study of the GM's role and authority in II 5 upscale European hotels finds a mixed picture in decision autonomy, depending on the individual's experience and education, as well as whether the hotel is independent or chain managed. Overall, independent GMs have greater autonomy in their properties than chain GMs, and highly experienced managers are often given greater autonomy by independent owners, while operating companies give greater autonomy to GMs who offer a combination of education and experience. With regard to individual functional areas, chain GMs have relatively greater authority in human resources, marketing, and strategy but limited autonomy in finance and operations.
\end{abstract}

\section{Keywords}

hotel management; operations; human resources; organizational governance and control; strategic management

Years of research have confirmed the long-held notion that the general manager (GM) is fundamental to a hotel's success (e.g., Forte 1986; Mayock 2012; Woods et al. 1998). But many contemporary GMs do not have unfettered control of their property, even though they are formally in charge of their hotel (or, more generally, a business unit, per Mintzberg 1975), oversee all of their property's functional departments (Nebel and Ghei 1993), and are held accountable for achieving property-level objectives (Morey and Dittman 2003; Woods et al. 1998). Instead, GMs are responsible to hotel owners or to superiors in a corporate management firm hierarchy (Corgel, Mandelbaum, and Woodworth 2011). Given the current hotel structure, a GM's authority to make key property-level decisions will first and foremost depend on the level of autonomy the GM is afforded. So far, we have seen few studies of the extent of GMs' autonomy or the effects of restrictions on their authority.

In this paper, we use the formulation of autonomy by Brooke $(1984,9)$, which is the extent to which units or subunits of an organization "possess the ability to take decisions for themselves on issues which are reserved to a higher level in comparable organizations." More simply, autonomy is the degree to which one may make important decisions without the consent of others (Brock 2003). The reason for this inquiry is the dramatic changes to the ownership and management structures in the hotel industry during the last thirty years (Slattery 2012). In many hotel structures, the GM manages property-level issues according to the owner's or operator's specifications and achieves the objectives of the owner and of the hotel management company (HMC), if the hotel is operated under a management contract. Even small hotels that are owner-operated must still meet outside standards if they have a franchise arrangement.

Although the GM is an employee of the HMC in hotels with a management contract, the relationship between the $\mathrm{GM}$ and the owner or HMC has many aspects of that of a principal and agent, because the manager as an agent can potentially act in a way that is not exactly what the principal would do (Eisenhardt 1989; Jensen and Meckling 1976; Anurag Sharma 1997). Given the position's responsibilities and reporting structure, the GM is effectively the primary agent acting on behalf of the principals. As such, the owner or management firm will be interested in controlling or monitoring the GM's behavior to ensure it is aligned with their own interests (Jensen and Meckling 1976). The GM's autonomy in making decisions for the property is thus subject to the influence of owners or management companies.

\footnotetext{
'Ecole hôtelière de Lausanne, Switzerland

${ }^{2}$ Cornell University, Ithaca, NY, USA

Corresponding Author:

Demian Hodari, Ecole hôtelière de Lausanne, Route de Cojonnex 18 , Lausanne, 1000-25, Switzerland.

Email: demian.hodari@ehl.ch
} 
Understanding the scope and limits of GMs' decision autonomy is an understudied yet important topic for hospitality research. While the greater complexity associated with contemporary governance structures in the hotel industry is now widely recognized (e.g., Corgel, Mandelbaum, and Woodworth 2011; deRoos and Eyster 2009; Olsen, Tse, and West 2008; Singh et al. 2012; Slattery 2012), hospitality research lacks a clear understanding of how these new structures have affected the GM's role, despite the fact that the position clearly has changed in recent years (Guerrier and Lockwood 1989; Jones and Davies 1991).

We are particularly interested in the level of autonomy granted to the GM in different aspects of the hotel operation. The greater the autonomy, the higher the cost of monitoring the GMs' agent-like behavior (Jensen and Meckling 1976). But autonomy also has a considerable potential value. Substantial research argues that more autonomy is better - it can lead to greater creativity (e.g., Liu, Chen, and Yao 2011), higher motivation (e.g., Ryan and Deci 2000), and improved performance (e.g., Hackman and Oldham 1976; Morgeson and Humphrey 2008). While certainly the empowerment and autonomy of the hotel industry's frontline employees and their direct supervisors have been studied extensively (e.g., Fulford and Enz 1995; Hales and Klidas 1998; Jones and Davies 1991; Raub and Robert 2013), this is not the case for the GM, despite this position's critical role in helping the hotel to succeed. This is also surprising, given what is effectively an agency dilemma, which involves the inherent conflict between autonomy as a best practice (e.g., Barling, Kelloway, and Iverson 2003; Evans and Davis 2005) and the risks of inadequate control (e.g., Gomez-Mejia and Balkin 1992).

Not surprisingly, the limited research on GMs' autonomy has found contradictory results. One study found that GMs have large discretion at work (Dann 1991), while a later study found that GMs had a relatively low locus of control which was correlated with, but not predicted by, self-determination (a construct similar to autonomy; Salazar, Pfaffenberg, and Salazar 2006). Another study found that the amount of empowerment perceived by the GMs was primarily associated with the company rather than with individual variables (Jones and Davies 1991). Similarly, Takeuchi, Shay, and Li (2008) found that the decision autonomy of expatriate hotel GMs was positively related to the degree of operational experience of the foreign subsidiary. In short, research tells us that autonomy can vary across organizations and units and can, at least in part, be predicted by individual and organizational characteristics. But beyond this general conclusion, there is little consistent insight into how GM autonomy varies and what characteristics may predict the level of autonomy that specific GMs receive.

Returning to the agency dilemma, studies have supported both greater and smaller levels of GM autonomy.
Expanding on the arguments we cited above, findings in favor of autonomy include GMs' preference (Worsfold 1989), reduction of turnover (Birdir 2002) and burnout (Kim, Shin, and Umbreit 2007; Ross 1997), and increased motivation (Jones and Davies 1991) and job satisfaction (Salazar, Pfaffenberg, and Salazar 2006). Beyond the GM, autonomy also plays a critical role in employee empowerment (Blanchard, Carlos, and Randolph 1999; Kanter 1993; Randolph 2000), which is correlated with faster (Bowen and Lawler 1995) and better service (Geralis and Terziovski 2003; He, Murrmann, and Perdue 2010), as well as increased customer satisfaction (Bradley and Sparks 2000; Brymer 1991; Yagil 2006).

The chief argument against GM autonomy is the principals' wish to maintain control over their operation. This seems to be a current hotel industry trend, as evidenced by increasingly higher degrees of centralization (Burgess 2004). Reduced GM autonomy would mean greater involvement by principals in the hotel's key decisions. Such involvement would reduce the information asymmetry in the principal-agent relationships (Anurag Sharma 1997) because the principals would have access to the key information necessary to make and evaluate the managers' decisions. This also limits the opportunities GMs have to act in their own self-interest, especially in terms of opportunistic and risky decisions (Jensen and Meckling 1976).

These studies predict that we should find differences in the level of autonomy granted to GMs, depending on a company's governance structure, reporting relationships, and organizational characteristics, such as its size. Furthermore, human capital variables, such as the GM's skills, experience, and education, may be considered by owners and management companies when delegating decision-making autonomy to the GM.

With that background, the purpose of this paper is to consider the nature of the modern GM's role and begin filling in the knowledge gap about GMs' decision autonomy overallin five functional areas. We investigate the level of autonomy that GMs have on operational, human resource, marketing, financial, and strategic issues for their properties by studying the relative level of involvement of GMs, owners, and management companies in these areas. We also compare this autonomy across property sizes and levels of GMs' human capital.

\section{Literature Review}

\section{Managerial Functions}

As research has shown that a GM's autonomy can vary across functional areas (Vachani 1991), understanding that autonomy requires examining the various functional roles the GM may play, and thus to what extent a principal would wish to limit the autonomy of GMs in these areas. 
Researchers have divided GMs' responsibilities into five main areas: strategy, operations, marketing, human resources, and finance (Aldehayyat 2011; Harper, Brown, and Irvine 2005; Ladkin 2002; Nebel and Ghei 1993; Nebel, Lee, and Vidakovic 1995; O’Neill 2000; Phillips 2000). Thus, we consider these five dimensions of autonomy as discussed below.

Operations. Most obviously, the GM is the person primarily responsible for the hotel's operations (Ladkin 1999) but who also must follow and enforce operating standards and procedures (Lenehan 2000). Those operating procedures are imposed by the HMC in properties with management contracts (O'Neill and Mattila 2010; O'Neill and Xiao 2006) but that may not be the case in independent hotels, depending on their approach to service delivery (Jones and Lockwood 2004). Regardless of who sets the standards, most GMs have acquired extensive operational experience throughout their careers (Harper, Brown, and Irvine 2005). We posit that their level of qualification grants them greater autonomy.

Human resources. Although management firms have specific human resources practices, GMs are extensively involved in human resource management (HRM) issues. In fact, HRM issues are regularly cited as the most troubling for both GMs and corporate executives (Enz 2001, 2009). Even if the chain mandates strategic HRM practices (Gannon, Doherty, and Roper 2012), and even if employee selection, training, and development procedures are often subject to company-wide policies, most of the staff is hired and trained at the unit level (Maxwell and Watson 2006). GMs can control their staff only so far, however, since supervisors and managers at the unit are often transferred across properties as part of corporate development programs. Independent hotels, meanwhile, are solely responsible for their own HRM issues, though this is an area where owners have been known to involve themselves (Guilding 2006; Nolan 2002).

Marketing. Most chain operators maintain large regional sales efforts and set brand standards. Within that framework, GMs have certain marketing responsibilities and are responsible for reaching performance targets. In addition to marketing services, management companies are also able to offer various distribution services that independent hotels may not be able to equal, including proprietary distribution channels, yield management systems, and loyalty programs (O'Neill and Carlbäck 2011), each of which involves its own set of procedures and policies. While independent hotels may have variations of these, and though they may belong to voluntary chains and marketing consortia to gain some of the distribution advantages normally associated with chain-affiliated hotels (Holverson and Revaz 2006), the GM's autonomy over marketing decisions may be less restricted in these hotels due to the presence of fewer formal policies.

Financial matters. Given the critical nature of management of revenues and expenses, as well as financing and accounting, at the hotel unit level (Singh and Schmidgall 2005), we anticipate that the principals would exert considerable control in this area. The GMs are often responsible for deciding how to reach specific financial objectives for their properties (Harris and Mongiello 2001) but that latitude does not necessarily extend to all governance structures. Burgess (2004) suggests that HMCs may effectively maintain company standards by centralizing financial and accounting processes at corporate levels and delegating some decision making to the property. Even when the GM has a choice of financial performance indicators, that selection is often influenced by the corporate level in HMC-operated hotels (Mongiello and Harris 2006). In addition, the terms of management contracts typically bind management firms to specific financial objectives (Eyster 1997). Independent properties, meanwhile, are not subject to corporate influence on financial measures and targets, and thus their GMs may have more autonomy on financial issues. Nonetheless, given the critical nature of financial outcomes from the owner's perspective, it is likely that autonomy constraints will be greater in financial issues than with the operations, HR, and marketing responsibilities discussed above. Regardless of the corporate structure, the financial skills of many GMs have been found to be inadequate (Burgess 2007; Desouza and Awazu 2004). As such, owners and management companies may be reluctant to afford latitude to any but the most qualified GMs with regard to financial decisions.

Strategy. Studies have been mixed on whether GMs are being given greater strategic planning authority (Olsen 1991), or whether the GMs have experienced declining responsibility for strategic decisions (Gilbert and Guerrier 1997; Hodari and Roper 2009). It appears that GMs in HMC-operated hotels are constrained with regard to strategy since they are subject to their parent company's strategic choices, and thus are not free to make all of their own decisions (Ramanathan 2012). Since independent hotels lack corporate-level specialists and formal structures designed for creating or implementing strategies, however, independent hotels may, in fact, rely more on the GM for strategic decisions. As with financial matters, this may be an area where only those with formal strategic planning qualifications may be granted autonomy over such decisions (cf., Harper, Brown, and Irvine 2005).

As we see from this discussion, an overall measure of autonomy would be too coarse a construct to depict the nature of the hotel GM position. Instead, we anticipate 
different levels of autonomy based on the five functional tasks engaged in by the GM rather than there being one overarching factor. Hence, we hypothesize as follows:

Hypothesis 1: GMs' decision autonomy is determined according to functional discipline.

Not only do we expect levels of autonomy to differ by functional discipline but we also see likely differences according to ownership structure because each hotel is an individual entity that must be, at least to some degree, managed as a separate business unit (Nebel and Ghei 1993). The $\mathrm{GM}$, under any structure, is responsible for the day-to-day operations of the business unit. While external authorities may certainly affect the nature of the GM's position, such controls are general and strategic and do not deal with specific momentary issues. Based on their experience in operations, marketing, and HR management, and the day-to-day demands of these functions, we expect GMs will have more discretion in those functional areas than they have for longer-term or more strategic "big picture" tasks (i.e., finance and strategy). Thus, we hypothesize as follows:

Hypothesis 2: GMs have a higher degree of decision autonomy on operational, marketing, and human resources issues than on financial and strategic issues.

\section{Governance Structures}

The ownership and management structure of the hotelthat is, whether the hotel is independent or HMC operated - should also affect the GM's responsibilities and, hence, autonomy. The independent hotels we are studying are neither affiliated with any brand or chain, nor are they operated by one of the independent management companies that operate both unbranded and branded hotels on behalf of owners. Because independent hotels are largely free to operate with fewer imposed restrictions, GMs should have relatively high levels of freedom for managing their hotels. Of course, even in independent hotels, if the owner is not also the GM, we would not expect owners to be completely uninvolved in the management of their assets (Birdir 2002). We think owners may directly exert influence over property-level decisions (e.g., Beals 1995; Eyster 1997; Schlup 2004). This may especially be the case in luxury hotels due to "ego-trip ownership" (Guilding 2006) since such owners enjoy being involved in the management of their "trophy assets." Another development in this regard is the rise of professional asset managers (Feldman 1995; Singh et al. 2012), whose expert knowledge and experience are also likely to reduce the GM's autonomy.

However, it seems likely that GMs in hotels operated by management firms face a wider range of stakeholders with whom they must work and garner support (Brookes and
Roper 2012). Although management contracts have always given the HMCs complete responsibility for a hotel, including the "exclusive right to supervise, direct and manage the property on behalf of the owner" (Bell 1993, 29), owners may nevertheless have some influence, depending on their bargaining power as represented in the terms of the management contract (deRoos 2010). GMs of these properties may thus be influenced not only by the HMC but also the owner (Gannon, Roper, and Doherty 2010).

We therefore expect independent hotels to employ fewer control mechanisms than are found in hotels operated by HMCs due in part to the complexities of a management contract. First, because management companies operate multiple properties, monitoring costs will be reduced due to greater efficiencies and economies of scale. Second, in HMC-operated hotels, the GM may effectively have two principals (Child and Rodrigues 2003), the owner and the $\mathrm{HMC}$, thereby requiring more limitations on the GM's role. In contrast, the independent hotel should require the GM to perform the widest range of functions, as it has the fewest forms of external resources upon which to draw. Thus, we predict as follows:

Hypothesis 3: GMs of independent hotels have more decision autonomy than GMs of HMC-operated hotels on operational, marketing, human resources, financial, and strategic issues.

\section{Hotel Size}

Researchers have long understood that as organization size increases, communication, coordination, and social control become more difficult (Child 1972; Khandwalla 1972; Lawrence and Lorsch 1967). Indeed, one reason that hotels are increasingly operated under management contracts is the industry's growing complexity and competitiveness (Morrison and Conway 2007). Size adds to complexity, which may therefore create more incentives for principals to limit managerial autonomy. This in turn increases rigidity as agents redistribute resources to support control functions and rely on increasingly bureaucratic procedures rather than on more ad hoc methods (Abemathy, Clark, and Kantrow 1983; Ettlie 1983). As a result, larger organizations often implement administratively oriented control through formalized, standardized, and more frequent communication to systematize the information needed for coordination and control purposes (Bruns and Waterhouse 1975; Merchant 1981).

Another reason that increased hotel size may mean more controls on the GM is that larger hotels represent larger investments. With more money at risk, principals will have a greater desire to monitor and control their agent's behaviors. An additional reason that GM autonomy may be reduced in a large property is the perceived need for more 
specialization in sales and other functions. As larger hotels employ more people, it follows that there would be a greater number of HRM issues at these properties, meaning that their GMs may be afforded less autonomy in making employee-related decisions so as to ensure greater consistency, especially as such hotels can also take advantage of economies of scale for HR practices (Way 2002). As well, larger hotels experience greater control of their resource utilization through more formal planning and monitoring (Arun Sharma 2002), which would restrict the autonomy provided to these properties' GMs. In addition, as larger hotels are more capital intensive and generate greater sales and expenses, owners and HMCs may be less inclined to afford GMs high levels of autonomy due to the greater financial risks.

Smaller firms, however, generally rely on interpersonal control, where the mechanisms used to control, coordinate, and communicate are more personal and informal (Bruns and Waterhouse 1975). Similarly, owners and managers of small firms, who tend to have closer interaction with operations and employees, are more likely than their counterparts in larger organizations to influence management practices through their personal preferences and attitudes (Wiesner, McDonald, and Banham 2007). Thus, while we expect GMs to have greater responsibility in the areas of operations, HR, and marketing than in finance and strategy (Hypothesis 2), and we expect this difference to be moderated in part by the management structure (Hypothesis 3), we also believe the difference will be further moderated by hotel size. Hence, we predict as follows:

Hypothesis 4: Hotel size will be negatively related to GMs' autonomy across functional areas.

\section{Human Capital}

Since agency theory also states that the nature of the agentprincipal relationship is a function of the parties' bargaining power (Jensen and Meckling 1976), we need to examine the GM's human capital. Not only can knowledge, skills, and abilities be a source of bargaining power but it is also logical that a principal would impute more authority to an educated, experienced GM. A high level of human capital may allow a GM to gain more autonomy and that may give the GM the capacity to work more effectively in the principal's interests if given more autonomy.

As trained and experienced professionals, GMs possess a wide range of knowledge that is specific to their situations (Abbott 1988; Anurag Sharma 1997). Anurag Sharma (1997) suggests that professionals have higher levels of specialized education and experience and often have a great deal of autonomy and control over their work. In consideration of this expertise, owners and management companies may therefore provide greater degrees of autonomy to hotel
GMs who have more education and experience. This gives the GM a wider range to effectively manage the hotel on their behalf, and this broader autonomy also acknowledges the GM's specialized knowledge and experience. In some cases, the principals may not be qualified to intervene since they do not have this specialized knowledge (Freidson 1983; Anurag Sharma 1997). GMs who possess greater levels of human capital should, therefore, be capable of maintaining greater autonomy in their job functions. Hence, we hypothesize as follows:

Hypothesis 5a: GMs' decision autonomy is positively related to their experience.

Hypothesis 5b: GMs' decision autonomy is positively related to their level of education.

\section{Method}

\section{Sample}

We collected survey data from 115 members of the European Hotel Managers Association (EHMA), who are GMs of both independent and HMC-operated luxury and upper upscale hotels. We sent online surveys to the association's 316 active members, giving them links either to a survey for GMs of managed properties or of independent properties. There were no significant differences in the response rate of GMs across the two questionnaires, which were identical, save for the reference to either "HMC" or "owner" throughout.

The 115 usable responses represent a response rate of 36 percent, which compares favorably to typical response rates in online surveys. For the few questions that some GMs did not complete, we imputed a value using maximum-likelihood-based methods, using the JMP software package (SAS Institute Inc. 2012). We believe that our relatively high response rate is due both to the GMs' interest in the topic and to the fact that these results would be presented at the EHMA annual conference. The data were collected in March 2011 and presented to and discussed with EHMA members the following month.

\section{Measures}

Ownership and human capital variables. EHMA members were told to consider their hotel to be independent if there was no management contract with any company operating multiple hotels. Any hotel under management contract with a formal business entity that operated multiple hotels was classified as HMC operated. Thus, this variable was coded as a dummy variable, where independent was the base case set to 0 , and HMC was set equal to 1 . Under this rubric, independent hotels made up 44 percent of the sample. 
Exhibit 1:

Summary Statistics $(N=115)$.

\begin{tabular}{lccccccccccc}
\hline & $M$ & $S D$ & 1 & 2 & 3 & 4 & 5 & 6 & 7 & 8 & 9 \\
\hline I. Experience & 2.68 & 1.05 & - & & & & & & & & \\
2. Education & 2.09 & 0.76 & -.13 & - & & & & & & \\
3. Number of rooms & 284 & 355 & -.16 & .01 & - & & & & & \\
4. Independent versus HMC & 0.44 & 0.50 & -.16 & .04 & .42 & - & & & & \\
5. Operations autonomy & 3.76 & 1.05 & .29 & -.04 & -.28 & -.45 & $(.80)$ & & & \\
6. Marketing autonomy & 4.18 & 1.10 & .21 & -.01 & -.21 & -.37 & .75 & $(.92)$ & & \\
7. Human resource autonomy & 4.04 & 1.10 & .17 & .03 & -.23 & -.36 & .75 & .85 & $(.90)$ & \\
8. Financial autonomy & 3.47 & 1.06 & .11 & .06 & -.08 & -.08 & .68 & .65 & .65 & $(.90)$ & \\
9. Strategic autonomy & 3.94 & 1.11 & .05 & .03 & -.08 & .01 & .55 & .65 & .70 & .72 & $(.95)$ \\
10. Overall autonomy & 3.88 & 0.94 & .19 & .02 & -.20 & -.28 & .85 & .90 & .91 & .85 & .83 \\
\hline
\end{tabular}

Note. HMC $=$ hotel management company. Correlations of .18 or greater are significant at $p<.05$. For Independent versus HMC, Independent $=0$ and $H M C=I$. The value for number of rooms was log-transformed before any subsequent analyses. The mean and standard deviation reflect the raw value, but the correlations and all further analyses are based on the log-transformed value. Experience and education were categorical variables. For experience: I = less than five years; 2 = six to ten years; 3 = eleven to twenty years; $4=$ twenty-one to thirty years; $5=$ greater than thirty years. For education: I = less than a bachelor's degree; 2 = bachelor's degree; 3 = graduate degree. Coefficient alphas are reported in parentheses on the main diagonal when appropriate.

Hotel size, measured by the number of rooms, ranged from 14 to 2,230 (median $=180, M=284, S D=355$ ). For all analyses, we used the log-transformation of the number of rooms so as to reduce the leverage of high values and make the resulting error term more normally distributed. We also noted that independent hotels were notably smaller than HMC-operated hotels, as the mean number of rooms for independent hotels was 152 (median $=180, S D=124)$ versus 450 for HMC-operated hotels (median $=305, S D=467$ ).

Human capital was measured by asking respondents about their level of experience and education. Both were collected as categorical variables, with five categories for experience and three for education. The largest group of respondents reported experience of eleven to twenty years, and a bachelor's degree was the most common educational attainment. Detailed statistics are presented in Exhibit 1.

Decision autonomy. Using questions based on prior autonomy research (Bartlett and Ghoshal 1989; Takeuchi et al. 2008), responding GMs were asked to assess their influence on decisions related to the five areas of interest: strategy, operations, marketing, HR, and finance, using four questions for each. Ratings were provided on a Likert-type scale, ranging from 1, "Decisions taken at corporate level" ("by owner" for independent hotels), to 5, "You take the decision." Coefficient alphas of the operations autonomy were .80 ; the coefficient alphas for all the other measures were at or above .90 .

\section{Results}

To test the hypotheses, we used a combination of structural equations modeling, $t$ tests, and regression, with the summary statistics for the variables reported in Exhibit 1. We found that, overall, GMs reported more autonomy than our neutral (middle) point of the scale (i.e., all means were significantly greater than 3.0 at $p<.0001$ ), thus indicating that GMs do, indeed, carry substantial autonomy in their position. Nonetheless, the levels of autonomy varied notably across respondents (with all of the standard deviations being greater than 1$)$.

\section{Hypothesis I: Discipline Differences}

Our data generally supported Hypothesis 1 , which predicted that GMs' decision autonomy is determined according to functional discipline rather than being a single overall factor. To test this, we compared a hypothesized five-factor model (where the five autonomy constructs are, indeed, separate) to a number of alternative models. Results from these confirmatory factor analyses are reported in Exhibit 2.

Compared with the other seven models, the five-factor model represented the best fit to the data, significantly better than the next-best-fitting model $(p<.001)$. The various fit indices show acceptable levels of fit only for the fivefactor model: chi-square per $d f\left(\chi^{2} / d f\right)=1.51$, Normed Fit Index $(\mathrm{NFI})=0.90$, Comparative Fit Index $(\mathrm{CFI})=0.95$, Goodness-of-Fit Index (GFI) $=0.84$, and Root MeanSquare Error of Approximation (RMSEA) $=0.08$. Furthermore, all the factor loadings from the items to their latent factors were greater than 0.60 and all were significant at $p<.0001$ (see Exhibit 3). Altogether, these analyses support the view that GMs distinguish between functional areas when considering their level of autonomy, supporting Hypothesis 1. 


\section{Exhibit 2:}

\section{GFIs for the Different Models.}

\begin{tabular}{|c|c|c|c|c|c|c|}
\hline Model & $\chi^{2}$ & $\chi^{2} / d f$ & $\mathrm{NFI}$ & $\mathrm{CFI}$ & GFI & RMSEA \\
\hline I. Single-factor & 812.01 & 4.78 & 0.65 & 0.70 & 0.54 & 0.18 \\
\hline 2. Two-factor (a) & 586.70 & 3.47 & 0.75 & 0.80 & 0.65 & 0.15 \\
\hline 3. Two-factor (b) & 561.42 & 3.32 & 0.76 & 0.82 & 0.66 & 0.14 \\
\hline 4. Three-factor (a) & 449.43 & 2.69 & 0.81 & 0.87 & 0.73 & 0.12 \\
\hline 5. Three-factor (b) & 568.14 & 3.40 & 0.76 & 0.81 & 0.66 & 0.15 \\
\hline 6. Four-factor (a) & 546.88 & 3.33 & 0.77 & 0.82 & 0.67 & 0.15 \\
\hline 7. Four-factor (b) & 421.67 & 2.57 & 0.82 & 0.88 & 0.75 & 0.11 \\
\hline 8. Five-factor (hypothesized) & 233.54 & $1.5 \mathrm{I}$ & 0.90 & 0.95 & 0.84 & 0.08 \\
\hline
\end{tabular}

Note. GFI = Goodness-of-Fit Index; NFI = Normed Fit Index; CFI = Comparative Fit Index; RMSEA = Residual Mean-Square Error of Approximation. Model I: All factors load on a single latent construct.

Model 2: Construct I (operations, marketing, human resource); Construct 2 (financial, strategic).

Model 3: Construct I (operations, marketing, human resource, financial); Construct 2 (strategic).

Model 4: Construct I (operations, marketing, human resource); Construct 2 (financial); Construct 3 (strategic).

Model 5: Construct I (operations); Construct 2 (marketing, human resource); Construct 3 (financial and strategic).

Model 6: Construct I (operations); Construct 2 (marketing); Construct 3 (human resource); Construct 4 (financial and strategic).

Model 7: Construct I (operations); Construct 2 (marketing, human resource); Construct 3 (financial); Construct 4 (strategic).

Model 8: Construct I (operations); Construct 2 (marketing); Construct 3 (human resource); Construct 4 (financial); Construct 5 (strategic).

\section{Exhibit 3:}

Factor Loadings for Five-Factor Model.

\begin{tabular}{lc}
\hline Construct and Scale Item & $\begin{array}{c}\text { Standardized } \\
\text { Loading }\end{array}$ \\
\hline Operations autonomy & \\
Changes in accommodation product & 0.67 \\
Changes in Food \& Beverage concepts & 0.72 \\
Choice of suppliers & 0.76 \\
Operating policies and procedure & 0.70 \\
Marketing autonomy & \\
Competitor analysis & 0.83 \\
Customer expectation analysis & 0.84 \\
Distribution channels selection & 0.92 \\
Pricing policies & 0.90 \\
Human resources autonomy & \\
Compensation policies & 0.81 \\
Performance management analysis & 0.79 \\
Recruitment and selection policies & 0.89 \\
Training and development policies & 0.85 \\
Financial autonomy & \\
Capital expenditures & 0.80 \\
Cash flow analysis & 0.77 \\
Operating budget & 0.89 \\
Profit loss analysis & 0.87 \\
Propategic autonomy & \\
Property's opportunities and threats & 0.99 \\
Property's organizational structure & 0.87 \\
Property's strengths and weaknesses & 0.91 \\
\hline & 0.88 \\
\hline
\end{tabular}

\section{Hypothesis 2: Greater Scope in Operations, Marketing, and $H R$}

Our data partially support Hypothesis 2, but with two unexpected twists, as we explain in a moment. With Hypothesis 1 supported, we continued to Hypothesis 2, which predicted that, overall, managers would have higher levels of autonomy for operations, marketing, and human resource functions than they would for financial and strategic functions. The top portion of Exhibit 4 shows comparisons (and $t$ tests of matched pairs' results) between all of the different dimensions of autonomy. These findings reveal mixed support for Hypothesis 2, due to the unexpected strength of strategic autonomy.

First, the results show that, as predicted, these GMs' operations autonomy, marketing autonomy, and human resource autonomy are greater than their financial autonomy ( $p<.001$ for operations and $p<.0001$ for marketing and human resources). Strategic autonomy, though, was higher than hypothesized; only marketing autonomy was significantly greater than strategic autonomy $(p<.01)$. Also counter to expectations, operations autonomy actually had a lower mean than strategic autonomy (mean difference of $0.18, p<.05)$.

Some other interesting, non-hypothesized results also emerged. We had expected relatively similar levels of autonomy for operations, marketing, and human resources. What we found, however, were significant differences in the average level of autonomy across these three dimensions. Operational autonomy was the lowest of the three (with the differences in the means significant at $p<.0001$ ), 


\section{Exhibit 4:}

Comparison of Autonomy across Dimensions and Governance Structures.

\begin{tabular}{|c|c|c|c|c|}
\hline Comparison (Variable I compared with Variable 2) & $\begin{array}{l}\text { Mean of } \\
\text { Variable I }\end{array}$ & $\begin{array}{l}\text { Mean of } \\
\text { Variable } 2\end{array}$ & Difference & Significance \\
\hline \multicolumn{5}{|l|}{ Comparison of autonomy dimensions } \\
\hline Operations autonomy versus marketing autonomy & 3.76 & 4.18 & -0.42 & $p<.0001$ \\
\hline $\begin{array}{l}\text { Operations autonomy versus human resource } \\
\text { autonomy }\end{array}$ & 3.76 & 4.04 & -0.28 & $p<.0001$ \\
\hline Operations autonomy versus financial autonomy ${ }^{a}$ & 3.76 & 3.47 & 0.29 & $p<.001$ \\
\hline Operations autonomy versus strategic autonomy ${ }^{\mathrm{a}}$ & 3.76 & 3.94 & -0.18 & $p<.05$ \\
\hline $\begin{array}{l}\text { Marketing autonomy versus human resource } \\
\text { autonomy }\end{array}$ & 4.18 & 4.04 & 0.14 & $p<.01$ \\
\hline Marketing autonomy versus financial autonomy ${ }^{\mathrm{a}}$ & 4.18 & 3.47 & 0.71 & $p<.0001$ \\
\hline Marketing autonomy versus strategic autonomy ${ }^{\mathrm{a}}$ & 4.18 & 3.94 & 0.24 & $p<.01$ \\
\hline $\begin{array}{l}\text { Human resource autonomy versus financial } \\
\text { autonomy }\end{array}$ & 4.04 & 3.47 & 0.57 & $p<.0001$ \\
\hline $\begin{array}{l}\text { Human resource autonomy versus strategic } \\
\text { autonomy }\end{array}$ & 4.04 & 3.94 & 0.10 & $p=.12$ \\
\hline Financial autonomy versus strategic autonomy & 3.47 & 3.94 & -0.47 & $p<.0001$ \\
\hline \multicolumn{5}{|c|}{ Comparison of independent hotels (Variable I) to HMC-operated hotels (Variable 2) } \\
\hline Operations autonomy ${ }^{\mathrm{a}}$ & 4.17 & 3.24 & 0.93 & $p<.0001$ \\
\hline Marketing autonomy ${ }^{\mathrm{a}}$ & 4.54 & 3.73 & 0.81 & $p<.0001$ \\
\hline Human resources autonomy ${ }^{a}$ & 4.38 & 3.60 & 0.78 & $p<.0001$ \\
\hline Financial autonomy ${ }^{\mathrm{a}}$ & 3.54 & 3.38 & 0.17 & $p=.21$ \\
\hline Strategic autonomy ${ }^{\mathrm{a}}$ & 3.94 & 3.95 & -0.01 & $p=.52$ \\
\hline Overall autonomy ${ }^{a}$ & 4.11 & 3.58 & 0.54 & $p<.001$ \\
\hline
\end{tabular}

Note. $\mathrm{HMC}=$ hotel management company. All significance tests are one-tailed .

a. Indicates that a positive difference was hypothesized.

while marketing autonomy was the highest (being statistically greater than human resource autonomy at $p<.01$ ).

We also had expected that the levels of financial and strategic autonomy would be similar, yet instead found that financial autonomy was significantly lower $(p<.0001)$ than that of strategy. Altogether, our examination of the means across the five autonomy dimensions revealed that there are more differences between the levels of autonomy provided in the different functional areas than we had originally supposed.

\section{Hypothesis 3: Comparing Independent and Chain Operations}

The picture was also mixed for autonomy in different functions for the two types of hotels. Hypothesis 3 predicted that GMs in HMC-operated hotels would have less autonomy than those in independent hotels. The lower portion of Exhibit 4, which reports the results of $t$ tests comparing these two groups, shows that this is the case overall but not across all functions. Even though our measure involves the five dimensions, we also considered an overall measure of autonomy, which combined all of the five measures of the various dimensions. Using that measurement, we found that
GMs in HMC-operated hotels had a lower level of overall autonomy than those in independent hotels $(p<.001)$

However, autonomy varied among the five functions taken separately. As we anticipated, compared with GMs in independent properties, the GMs in HMC-operated hotels had lower autonomy for operations, marketing, and HR (all at $p<.0001$ ) but that was not the case for financial or strategic autonomy.

\section{Hypothesis 4: The Effect of Hotel Size}

To test the effects of hotel size on the GMs' autonomy, we had to separate the HMC-operated and independent hotels. Because the hotel sizes were notably different for the two groups, considering both sets of hotels together in the same analysis could be problematic. We feared that ownership type could be confounded with hotel size and could obscure relationships (or create spurious relationships) because of the notable mean differences with the autonomy variables. Thus, to assess our last two hypotheses, we performed separate regression analyses for independent and HMC-operated hotels (see Exhibit 5).

Separating the two hotel subsets highlighted differences in the relationship of size and autonomy, contrary to the 


\section{Exhibit 5:}

Predicting the Level of General Manager Autonomy.

\begin{tabular}{|c|c|c|c|c|c|c|}
\hline & $\begin{array}{l}\text { Operations } \\
\text { Autonomy }\end{array}$ & $\begin{array}{l}\text { Marketing } \\
\text { Autonomy }\end{array}$ & $\begin{array}{c}\text { Human Resource } \\
\text { Autonomy }\end{array}$ & $\begin{array}{l}\text { Financial } \\
\text { Autonomy }\end{array}$ & $\begin{array}{l}\text { Strategic } \\
\text { Autonomy }\end{array}$ & $\begin{array}{c}\text { Overall } \\
\text { Autonomy }\end{array}$ \\
\hline \multicolumn{7}{|c|}{ Independent hotels $(N=64)$} \\
\hline Intercept & $\begin{array}{l}4.50 \\
(0.84) * * * *\end{array}$ & $\begin{array}{l}5.32 \\
(0.7 I) * * * *\end{array}$ & $\begin{array}{l}5.45 \\
(0.80) * * * *\end{array}$ & $\begin{array}{l}3.56 \\
(1.00) * * *\end{array}$ & $\begin{array}{l}4.19 \\
(0.73) * * * *\end{array}$ & $\begin{array}{l}4.60 \\
(0.79)^{* * * * *}\end{array}$ \\
\hline Experience & $\begin{array}{l}0.26 \\
(0.11)^{* *}\end{array}$ & $\begin{array}{l}0.31 \\
(0.10)^{* *}\end{array}$ & $\begin{array}{l}0.23 \\
(0.10)^{*}\end{array}$ & $\begin{array}{l}0.24 \\
(0.13)^{*}\end{array}$ & $\begin{array}{l}0.22 \\
(0.12)^{*}\end{array}$ & $\begin{array}{l}0.25 \\
(0.10)^{* *}\end{array}$ \\
\hline Education & $\begin{array}{c}0.08 \\
(0.16)\end{array}$ & $\begin{array}{l}-0.01 \\
(0.16)\end{array}$ & $\begin{array}{l}-0.01 \\
(0.16)\end{array}$ & $\begin{array}{c}0.23 \\
(0.19)\end{array}$ & $\begin{array}{c}0.02 \\
(0.19)\end{array}$ & $\begin{array}{l}0.06 \\
(0.15)\end{array}$ \\
\hline Ln (N rooms) & $\begin{array}{l}-0.26 \\
(0.15)^{*}\end{array}$ & $\begin{array}{l}-0.34 \\
(0.15)^{*}\end{array}$ & $\begin{array}{l}-0.36 \\
(0.15)^{* *}\end{array}$ & $\begin{array}{l}-0.25 \\
(0.18)^{\dagger}\end{array}$ & $\begin{array}{l}-0.19 \\
(0.18)\end{array}$ & $\begin{array}{l}-0.28 \\
(0.14)^{*}\end{array}$ \\
\hline Model $R^{2}$ & .11 & .17 & .13 & .08 & .06 & .12 \\
\hline \multicolumn{7}{|c|}{ HMC-operated hotels } \\
\hline Intercept & $\begin{array}{l}3.59 \\
(1.08)^{* *}\end{array}$ & $\begin{array}{l}4.36 \\
(1.37)^{* *}\end{array}$ & $\begin{array}{l}3.38 \\
(1.21)^{* *}\end{array}$ & $\begin{array}{l}3.38 \\
(1.21)^{* *}\end{array}$ & $\begin{array}{l}5.39 \\
(1.39)^{* * *}\end{array}$ & $\begin{array}{l}4.20 \\
(I . I I)^{* * * *}\end{array}$ \\
\hline Experience & $\begin{array}{l}0.21 \\
(0.08)^{\dagger}\end{array}$ & $\begin{array}{l}-0.03 \\
(0.18)\end{array}$ & $\begin{array}{l}-0.25 \\
(0.16)\end{array}$ & $\begin{array}{l}-0.02 \\
(0.16)\end{array}$ & $\begin{array}{l}-0.22 \\
(0.19)\end{array}$ & $\begin{array}{c}-0.02 \\
(0.15)\end{array}$ \\
\hline Education & $\begin{array}{l}-0.06 \\
(0.16)\end{array}$ & $\begin{array}{c}0.09 \\
(0.20)\end{array}$ & $\begin{array}{c}0.00 \\
(0.18)\end{array}$ & $\begin{array}{c}0.00 \\
(0.18)\end{array}$ & $\begin{array}{c}0.11 \\
(0.21)\end{array}$ & $\begin{array}{c}0.06 \\
(0.17)\end{array}$ \\
\hline Ln (N rooms) & $\begin{array}{l}-0.13 \\
(0.15)\end{array}$ & $\begin{array}{l}-0.13 \\
(0.19)\end{array}$ & $\begin{array}{l}0.01 \\
(0.17)\end{array}$ & $\begin{array}{l}0.01 \\
(0.17)\end{array}$ & $\begin{array}{l}-0.20 \\
(0.19)\end{array}$ & $\begin{array}{l}-0.13 \\
(0.15)\end{array}$ \\
\hline Model $R^{2}$ & .07 & .01 & .03 & .00 & .05 & .02 \\
\hline
\end{tabular}

Note. $\mathrm{HMC}=$ hotel management company. $B$ coefficients are reported in the top of each cell; standard errors are reported in parentheses. ${ }^{\dagger} p<.10 . *_{p}<.05 . * * p<.01 . * * * p<.001 . * * * * p<.0001$.

prediction in Hypothesis 4, which held that hotel size would be negatively related to decision autonomy. We find that not only do the two hotel types differ with regard to levels of autonomy but also the effect of hotel size on autonomy is notably different, depending in part on the function in question.

First, we found no significant relationship between hotel size and GM autonomy in hotels operated by management companies, either overall or for any of the dimensions. For independent hotels, though, hotel size was significantly negatively related to the aggregate measure of overall autonomy $(p<.05)$. However, this relationship varied by function. Again for independents, hotel size was negatively related to autonomy for operations, HR (both at $p<.05$ ), and marketing (at $p<.01$ ). The relationship was marginally non-significant for financial autonomy $(p<.10)$, and we found no relation for strategic autonomy.

\section{Hypothesis 5: The Importance of Human Capital}

The effects of human capital on autonomy also diverged between the two hotel types. Hypothesis 5 predicted that decision autonomy would be positively related to human capital characteristics, namely, experience (Hypothesis 5a) and education (Hypothesis 5b). As above, we performed separate regressions for independent and HMC-operated hotels, which revealed different patterns for the effects of human capital.

For independent hotels, our results showed consistent effects for experience but no main effects for education. Greater experience was associated with more autonomy for operations $(p<.01)$ and for all four of the other dimensions of autonomy $(p<.05)$. Likewise, the relationship of the aggregate measure of autonomy with experience was positive and significant $(p<.01)$. In contrast, there was no relationship between experience and autonomy for any of the individual dimensions or the overall measure in hotels operated by HMCs.

Since human capital is in reality a product of education and experience, we ran a second model that included the interaction of these two factors, with intriguing results. Once again, we separated independents and HMC-operated hotels for these regressions (see Exhibit 6), and both experience and education were mean centered before the interaction.

Although the interaction term was not significant for any of the regression models involving independent hotels, we saw a clear effect for HMC-operated hotels. The interaction term was significant for all five autonomy dimensions $(p<$ .05 for strategic autonomy and $p<.01$ for the other four dimensions and the overall measure). This interaction 
Exhibit 6:

Predicting the Level of General Manager Autonomy with the Human Capital Interaction.

\begin{tabular}{lcccccc}
\hline & $\begin{array}{c}\text { Operations } \\
\text { Autonomy }\end{array}$ & $\begin{array}{c}\text { Marketing } \\
\text { Autonomy }\end{array}$ & $\begin{array}{c}\text { Human Resource } \\
\text { Autonomy }\end{array}$ & $\begin{array}{c}\text { Financial } \\
\text { Autonomy }\end{array}$ & $\begin{array}{c}\text { Strategic } \\
\text { Autonomy }\end{array}$ & $\begin{array}{c}\text { Overall } \\
\text { Autonomy }\end{array}$ \\
\hline Independent hotels & & & & & & \\
Intercept & 4.50 & 5.32 & 5.45 & 3.56 & 4.18 & 4.60 \\
& $(0.85)^{* * * *}$ & $(0.81)^{* * * *}$ & $(0.81)^{* * * *}$ & $(1.00)^{* * *}$ & $(0.97)^{* * * *}$ & $(0.79)^{* * * * *}$ \\
Experience & 0.26 & 0.31 & 0.23 & 0.21 & 0.20 & 0.24 \\
& $(0.11)^{*}$ & $(0.10)^{* *}$ & $(0.10)^{*}$ & $(0.13)^{*}$ & $(0.13)^{\dagger}$ & $(0.10)^{*}$ \\
Education & 0.08 & -0.01 & -0.01 & 0.23 & 0.01 & 0.05 \\
& $(0.17)$ & $(0.16)$ & $(0.16)$ & $(0.19)$ & $(0.19)$ & $(0.16)$ \\
Ln (N rooms) & -0.26 & -0.34 & -0.36 & -0.22 & -0.18 & -0.27 \\
& $(0.15)^{*}$ & $(0.15)^{*}$ & $(0.15)^{* *}$ & $(0.18)$ & $(0.18)$ & $(0.15)^{*}$ \\
Experience $\times$ Education & -0.05 & 0.02 & 0.00 & -0.25 & -0.14 & -0.08 \\
& $(0.17)$ & $(0.16)$ & $(0.16)$ & $(0.20)$ & $(0.19)$ & $(0.16)$ \\
Model $R^{2}$ & .11 & .17 & .13 & .11 & .06 & .13 \\
HMC-operated hotels & & & & & \\
Intercept & 3.47 & 4.21 & 4.06 & 3.21 & 5.26 & 4.04 \\
& $(1.02)^{* *}$ & $(1.30)^{* *}$ & $(1.23)^{* *}$ & $(1.10)^{* *}$ & $(1.35)^{* * *}$ & $(1.01)^{* * * *}$ \\
Experience & 0.29 & 0.07 & 0.13 & 0.08 & -0.14 & 0.09 \\
& $(0.14)^{*}$ & $(0.18)$ & $(0.17)$ & $(0.15)$ & $(0.19)$ & $(0.14)$ \\
Education & -0.10 & 0.03 & 0.10 & -0.07 & 0.06 & 0.00 \\
& $(0.15)$ & $(0.20)$ & $(0.19)$ & $(0.17)$ & $(0.20)$ & $(0.15)$ \\
Ln $(N$ rooms) & -0.12 & -0.12 & -0.16 & 0.02 & -0.19 & -0.11 \\
& $(0.14)$ & $(0.18)$ & $(0.17)$ & $(0.15)$ & $(0.19)$ & $(0.14)$ \\
Experience $\times$ Education & 0.47 & 0.57 & 0.78 & 0.63 & 0.48 & 0.59 \\
& $(0.18)^{* *}$ & $(0.23)^{* *}$ & $(0.22)^{* * * *}$ & $(0.19)^{* *}$ & $(0.24)^{*}$ & $(0.18)^{* * *}$ \\
Model $R^{2}$ & .20 & .13 & .25 & .19 & .12 & .21 \\
\hline
\end{tabular}

Note. $\mathrm{HMC}=$ hotel management company. $B$ coefficients are reported in the top of each cell; standard errors are reported in parentheses. ${ }^{\dagger} p<.10 .{ }^{*} p<.05 . * * p<.01 .{ }^{* * *} p<.001 . * * * * p<.0001$.

variable added notable explanatory power, raising the level of $R$-square in the models by .07 in the prediction of strategic autonomy, by more than .10 for operations and marketing autonomy, and by roughly .20 for predicting human resource and financial autonomy. When looking at the overall measure of autonomy, adding the interaction term increased the $R$-square from .02 to .21 .

\section{Discussion}

These results confirm our opening proposition that autonomy is a complex, multidimensional construct for hotel GMs, one that varies by the job's functional duties. While GMs do appear to have substantial overall autonomy in their position, the level of autonomy depends on the decision type, the hotel's governance structure, and the managers' own abilities.

With regard to the functional area, we were surprised by two of our findings. First, our prediction of lower autonomy in strategic issues did not hold true when compared with the other functional areas (except for finance, which, as predicted, did have lower autonomy than for operations, marketing, and human resources). While GMs may have lacked experience and training in strategic planning in the past, the training and education of GMs have clearly evolved. For example, hotel school curricula have increasingly shifted from a practical and technical training program to one that is more business oriented (Okumus and Wong 2004), and strategy courses form a component in many of these (Okumus and Wong 2005; Okumus, Wong, and Altinay 2009). Moreover, this educational evolution could also have found its way into corporate management development programs and the executive education courses offered at academic institutions because the formal training in strategic planning is increasingly seen as an important skill for those wishing to become GMs (Harper, Brown, and Irvine 2005). With those educational changes, not only may GMs be better prepared for these decisions but also their superiors may have the confidence to entrust such decisions to them. In addition, competition is largely a local affair, and thus the GM may be seen as the best person to take decisions based on knowledge of the competitive market.

The second finding about functional autonomy that surprised us was that the GMs reported having less operational autonomy than they possessed in all other areas besides finance. We had expected that GMs' extensive operational 
experience and the sometimes spontaneous nature of operations would mean that GMs would need greater latitude here. Our findings suggest, however, that this is not the case. We believe this is in large part a consequence of the industry's intense focus on brand management (O'Neill and Mattila 2010), which entails strict operating standards to protect brand integrity. While this has long been the case for management companies, the shift toward the independent hotel owner as an investor who often owns multiple hotels could imply that such investors have sought to replicate some of the management companies' advantages by insisting on more top-down policies for operational consistency. In addition, operations may not be seen as being as difficult as sales and marketing (due to evolving technological advancements) or as delicate as HR issues (due to legal ramifications), and therefore could be an area where owners feel more able to involve themselves even though they lack specialized knowledge or experience.

As predicted, we found that GMs in HMC-operated hotels have lower autonomy in operations, marketing, and HR management than those in independent properties. We did not, however, find that the same held true for strategy and finance, neither of which was dependent on the governance structure. This finding may call for a revision of the view that independent hotels lack strategic planning practices (Amit Sharma 2008). We think that principals, be they independent owners or management companies, prefer to remain more involved in financial and strategic issues since these are key value-adding functions that they can provide. Institutional owners are often professional real estate investment groups with strong resources and professional management know-how, including asset managers (Ambrose et al. 2000; Woolley et al. 1997). As these investors often also have specific and short-term investment horizons for their properties, they may be more involved in strategic and financial decisions, and thus may mirror the policies and involvement levels of the HMCs. The same may be true for individual owners since the fact that they own a hotel means they are entrepreneurial, think strategically, and may see it as their responsibility to oversee their investment's direction. It may also be that GMs are still largely seen as more operational than business oriented, and as such may still be regarded by the principals as innkeepers rather than business directors. If that is the case, such managers would be subjected to the involvement of the principals in these "business" areas regardless of the governance structure.

The different effects of organizational size for independent and HMC-operated hotels were also interesting. Management firms seem to be consistent in terms of GM autonomy regardless of their hotel's size, and they use other criteria for autonomy considerations. In independent hotels, however, size mattered; GMs' autonomy declined as the size of the independent hotels increased. As we mentioned above, we believe that owners of independent hotels are less willing to delegate authority as their investment increases.

The effects associated with human capital also varied for the two hotel types. Independent hotels provided more autonomy for GMs who had more experience but not those with more education. In contrast, neither education nor experience alone mattered in HMC-operated hotels, but a manager who combined experience and education was given higher levels of autonomy in all areas. Thus, one cannot make general statements about how the industry values education or experience in its GMs. Our results show that independent hotels seem to value experience but not education. In contrast, HMCs recognize the benefit of the combination of education and experience.

\section{Managerial Implications}

Our results demonstrate that the differences in various GMs' decision autonomy may reside as much with a particular GM's human capital as with a hotel's ownership and management structures. GMs may benefit from continuing education, but only in HMC-operated hotels, and only if the manager has the requisite experience to match. In independent hotels, it is only experience that appears to lead to higher levels of autonomy, regardless of education.

Given that lower autonomy has been associated with greater job burnout in the hotel industry (Kim, Shin, and Umbreit 2007), choices about education and training could have important career implications. Moreover, both management companies and owners may find a better fit with GMs whose aspirations toward autonomy align with their own philosophies regarding decentralization and empowerment. One clear implication is for realistic recruitment whereby owners and management companies may consider discussing expected autonomy levels with prospective GMs.

Individuals seeking to attain the role of GM, which has often been described as a "target job" (e.g., Ladkin 1999), may also benefit from focusing on the traditional areas of operations, marketing, and HR since these appear to be the areas in which owners and HMCs expect their GMs to focus and excel. We do not suggest that finance and strategy are unimportant for the hotel or the GM's career (especially since strategy seems to be gaining in importance), but only that skills in these areas may not be the deciding factor for attaining the GM position. Those seeking to become GMs may want to consider whether their career path will bring them to independent or HMC-operated hotels. GMs who work for HMCs or who feel they may pursue jobs in HMCoperated hotels are also encouraged to gain advanced degrees if they also wish to improve their chances for being given autonomy. Alternatively, GMs with extensive experience but limited education may want to seek employment specifically at independent hotels. 


\section{Contributions, Limitations, and Suggestions for Future Research}

Research about managerial work in the hospitality industry has almost always been restricted to the United States and has so far largely been inconclusive due to its predominantly exploratory, qualitative nature (e.g., Gannon, Roper, and Doherty 2010) and the small numbers of the studies' participants (e.g., Arnaldo 1981; Dann 1991; Ley 1980). Similarly, studies about hospitality industry managers' activities have generally sampled from a variety of industry sectors, functional levels, and departments (e.g., Gamble, Lockwood, and Messenger 1994; Kay and Russette 2000), thereby preventing any significant analysis about hotel GMs in particular. Furthermore, most research on GMs either predates or ignores the implications of different governance structures, although researchers largely agree that the involvement of HMCs and owners in property-level decisions has not yet received enough attention (Gannon, Roper, and Doherty 2010; Turner and Guilding 2010). This study sought, in part, to remedy these knowledge gaps, and thus focused on GMs of European hotels.

As with any research, though, our study's results should be interpreted with caution. First, our sample comprised one set of GMs who demonstrate commitment to their careers and industry by belonging to the invitation-only EHMA, which caters to GMs of upscale and luxury properties. Therefore, the findings may not necessarily generalize to all GMs, especially to those operating midscale, economy, or budget hotels. Similarly, as our sample was limited to GMs in Europe, we cannot assume that the findings generalize to other locations.

Because we collected the data through one source, we risk common method variance (CMV), although our analysis sought to control CMV to the extent possible. We did find divergent validity in our constructs, as Hypothesis 1 was strongly supported against a variety of alternative models. Furthermore, the regressions contained multiple independent variables that reduce the effect of any possible CMV (Siemsen, Roth, and Oliveira 2010). Finally, CMV would have made the separate regression results more similar, rather than having just notable differences between the independent and HMC-operated samples. Thus, we feel the potential risks of CMV are minimal.

Our findings also indicate several interesting opportunities for applied business research. First, because the two ownership structures we studied have such an impact on both the level of and relationships with GM decision autonomy, future research should delve more deeply into questions about the operating implications of ownership structure. While this study examines antecedents of dimensions of autonomy, research examining the implications of autonomy would have critical implications for practice.
Future research should examine the extent to which GM autonomy improves organizational performance (e.g., customer satisfaction, employee satisfaction, and financial measures). Second, because owners are increasingly using asset managers to oversee the performance of their independent and HMC-operated hotels, it could be useful to compare the relative influence of owners and asset managers on property-level decisions. Although asset managers are increasingly important for portfolio management, we have seen few studies regarding their effects on operational and financial performance (Singh et al. 2012). The way asset managers change the nature of the GM's work (if, indeed, they even do) would give organizations and owners better information as to what sort of effect employing an asset manager will have. Given the importance of the GM's position, we recommend that research on autonomy should continue, and further examination of the specific consequences of GMs' autonomy in the hospitality industry would be particularly valuable.

\section{Declaration of Conflicting Interests}

The author(s) declared no potential conflicts of interest with respect to the research, authorship, or publication of this article.

\section{Funding}

The author(s) received no financial support for the research, authorship, or publication of this article.

\section{References}

Abbott, A. 1988. The system of professions: An essay on the division of expert labor. Chicago: University of Chicago Press.

Abemathy, W. J., K. B. Clark, and A. M. Kantrow. 1983. Industrial renaissance. New York: Basic Books.

Aldehayyat, J. S. 2011. Organisational characteristics and the practice of strategic planning in Jordanian hotels. International Journal of Hospitality Management 30 (1): 192-99.

Ambrose, B. W., S. R. Ehrlich, W. T. Hughes, and S. M. Wachter. 2000. REIT economies of scale: Fact or fiction? The Journal of Real Estate Finance and Economics 20 (2): 211-24.

Arnaldo, M. J. 1981. Hotel general managers: A profile. The Cornell Hotel and Restaurant Administration Quarterly 22 (3): 53-56.

Barling, J. E., Kevin K., and R. D. Iverson. 2003. High-quality work, job satisfaction, and occupational injuries. Journal of Applied Psychology 88 (2): 276-83.

Bartlett, C. A., and S. Ghoshal. Managing Across Borders: The Transnational Solution. Boston:Harvard Business School Press.

Beals, P. 1995. The hotel management contract: Lessons from the North American experience. In Accounting and finance for the international hospitality industry, ed. Peter Harris, 27894. Oxford: Butterworth-Heinemann.

Bell, C. A. 1993. Agreements with chain-hotel companies. The Cornell Hotel and Restaurant Administration Quarterly 34 (1): $27-33$. 
Birdir, K. 2002. General manager turnover and root causes. International Journal of Contemporary Hospitality Management 14 (1): 43-47.

Blanchard, K., J. P. Carlos, and A. Randolph. 1999. The 3 keys to empowerment: Release the power within people for astonishing results. San Francisco: Berrett-Koehler.

Bowen, D. E., and E. E. Lawler. 1995. Empowering service employees. Sloan Management Review 36 (4): 73-84.

Bradley, G. L., and B. A. Sparks. 2000. Customer reactions to staff empowerment: Mediators and moderators. Journal of Applied Social Psychology 30 (5): 991-1012.

Brock, D. M. 2003. Autonomy of individuals and organizations: Towards a strategy research agenda. International Journal of Business and Economics 2 (1): 57-73.

Brooke, M. Z. 1984. Centralization and autonomy: A study in organizational behaviour. London: Holt, Rinehart and Winston.

Brookes, M., and A. Roper. 2012. Realising plural-form benefits in international hotel chains. Tourism Management 33 (3): 580-91.

Bruns, W. J., Jr., and J. H. Waterhouse. 1975. Budgetary control and organization structure. Journal of Accounting Research 13 (2): 177-203.

Brymer, R. A. 1991. Hospitality management: An introduction to the industry. Dubuque, IA: Kendall Hunt.

Burgess, C. 2004. Planning for the centralization of accounting in chain hotels. Tourism and Hospitality Planning \& Development 1 (2): 145-56. doi:10.1080/1479053042000251098

Burgess, C. 2007. Do hotel managers have sufficient financial skills to help them manage their areas? International Journal of Contemporary Hospitality Management 19 (3): 188-200.

Child, J. 1972. Organizational structure, environment and performance: The role of strategic choice. Sociology 6 (1): 1-22.

Child, J., and S. Rodrigues. 2003. Social identity and organizational learning. In Handbook of organizational learning and knowledge management, ed. Mark Easterby-Smith and Marjorie A. Lyles, 535-56. Oxford: Blackwell.

Corgel, J. B., Robert M., and R. M. Woodworth. 2011. Hospitality property ownership: Where you fit in. In The Cornell school of hotel administration on hospitality: Cutting edge thinking and practice, ed. Michael C. Sturman, Jack B. Corgel, and Rohit Verma. Hoboken: John Wiley \& Sons.

Dann, D. T. 1991. Strategy and managerial work in hotels. International Journal of Contemporary Hospitality Management 3 (2): 23-25.

deRoos, J. A. 2010. Hotel management contracts - Past and present. Cornell Hospitality Quarterly 51 (1): 68-80.

deRoos, J. A., and J. J. Eyster. 2009. Contemporary hotel management contracts. In Hotel asset management: Principles \& practices, 2nd ed., ed. Gregory A. Denton, Lory E. Raleigh, and A. J. Singh, 141-178. Lansing: Educational Institute of the American Hotel \& Lodging Association

Desouza, K. C., and Y. Awazu. 2004. "Need to know"-organizational knowledge and management perspective. Information, Knowledge, Systems Management 4 (1): 1-14.

Eisenhardt, K. M. 1989. Building theories from case study research. Academy of Management Review 14 (4): 532-50.

Enz, C. A. 2001. What keeps you up at night? Key issues of concern for lodging managers. The Cornell Hotel and Restaurant Administration Quarterly 42 (2): 38-45.
Enz, C. A. 2009. Human resource management a troubling issue for the global hotel industry. Cornell Hospitality Quarterly 50 (4): 578-83.

Ettlie, J. E. 1983. Organizational policy and innovation among suppliers to the food processing sector. Academy of Management Journal 26 (1): 27-44.

Evans, W. R., and W. D. Davis. 2005. High-performance work systems and organizational performance: The mediating role of internal social structure. Journal of Management 31 (5): 758-75.

Eyster, J. J. 1997. Hotel management contracts in the U.S.: Twelve areas of concern. The Cornell Hotel and Restaurant Administration Quarterly 38 (3): 21-33.

Feldman, D. S. 1995. Asset management here to stay. The Cornell Hotel and Restaurant Administration Quarterly 36 (5): 36-51.

Forte, C. 1986. Forte: The autobiography of Charles Forte. London: Sidgwick \& Jackson.

Freidson, E. 1983. The theory of professions: State of the art. In The sociology of professions: Doctors, lawyers and others, ed. Robert Dingwall and Philip Lewis, 19-37. London: Macmillan.

Fulford, M. D., and C. A. Enz. 1995. Human resources as a strategic partner in multiunit-restaurants. The Cornell Hotel and Restaurant Administration Quarterly 36 (3):24-29.

Gamble, P., Andrew L., and Sally M. 1994. Management skills in the European hospitality industry. Paper presented at 48th annual CHRIE conference, Palm Springs, CA.

Gannon, J. M., Liz D., and Angela R. 2012. The role of strategic groups in understanding strategic human resource management. Personnel Review 41 (4): 513-46.

Gannon, J. M., Angela R., and Liz D. 2010. The impact of hotel management contracting on IHRM practices: Understanding the bricks and brains split. International Journal of Contemporary Hospitality Management 22 (5): 638-58.

Geralis, M., and Mile T. 2003. A quantitative analysis of the relationship between empowerment practices and service quality outcomes. Total Quality Management \& Business Excellence 14 (1): 45-62.

Gilbert, D., and Yvonne G. 1997. UK hospitality managers past and present. Service Industries Journal 17 (1): 115-32.

Gomez-Mejia, L. R., and D. B. Balkin. 1992. Determinants of faculty pay: An agency theory perspective. Academy of Management Journal 35 (5): 921-55.

Guerrier, Y., and Andrew L. 1989. Developing hotel managers - a reappraisal. International Journal of Hospitality Management 8 (2): $82-89$.

Guilding, C. 2006. Investment appraisal issues arising in hotels governed by a management contract. In Accounting and financial management. Developments in the international hospitality industry, ed. Peter Harris and Marco Mongiello, 400-22. Oxford: Butterworth-Heinemann.

Hackman, J. R., and G. R. Oldham. 1976. Motivation through the design of work: Test of a theory. Organizational Behavior and Human Performance 16 (2): 250-79.

Hales, C., and Antonis K. 1998. Empowerment in five-star hotels: Choice, voice or rhetoric? International Journal of Contemporary Hospitality Management 10 (3): 88-95.

Harper, S., Caroline B., and Wilson I. 2005. Qualifications: A fast-track to hotel general manager? International Journal of Contemporary Hospitality Management 17 (1): 51-64. 
Harris, P. J., and Marco M. 2001. Key performance indicators in European hotel properties: General managers' choices and company profiles. International Journal of Contemporary Hospitality Management 13 (3): 120-28.

He, P., S. K. Murrmann, and R. R. Perdue. 2010. An investigation of the relationships among employee empowerment, employee perceived service quality, and employee job satisfaction in a U.S. hospitality organization. Journal of Foodservice Business Research 13 (1): 36-50.

Hodari, D., and A. Roper. 2009. Contextual influences on the role of strategy tools within an international hotel firm. Paper presented at EuroCHRIE, Helsinki, Finland.

Holverson, S., and Frédéric R. 2006. Perceptions of European independent hoteliers: Hard and soft branding choices. International Journal of Contemporary Hospitality Management 18 (5): 398-413.

Jensen, M. C., and W. H. Meckling. 1976. Theory of the firm: Managerial behavior, agency costs and ownership structure. Journal of Financial Economics 3 (4): 305-60.

Jones, P., and A. Davies. 1991. Empowerment: A study of general managers of four star hotel properties in the UK. International Journal of Hospitality Management 10 (3): 211-17.

Jones, P., and A. Lockwood. 2004. The management of hotel operations. London: Thomson Learning.

Kanter, R. M. 1993. Men and women of the corporation. New York: Basic Books.

Kay, C., and J. Russette. 2000. Hospitality-management competencies identifying managers' essential skills. The Cornell Hotel and Restaurant Administration Quarterly 41 (2): 52-63.

Khandwalla, P. N. 1972. The effect of different types of competition on the use of management controls. Journal of Accounting Research 10 (2): 275-85.

Kim, H. J., K. H. Shin, and W. T. Umbreit. 2007. Hotel job burnout: The role of personality characteristics. International Journal of Hospitality Management 26 (2): 421-34.

Ladkin, A. 1999. Hotel general managers: A review of prominent research themes. International Journal of Tourism Research 1 (3): 167-93.

Ladkin, A. 2002. Career analysis: A case study of hotel general managers in Australia. Tourism Management 23 (4): 379-88.

Lawrence, P. R., and J. W. Lorsch. 1967. Differentiation and integration in complex organizations. Administrative Science Quarterly 12 (1): 1-47.

Lenehan, T. 2000. A study of management practices and competences within effective organisations in the Irish tourism industry. Service Industries Journal 20 (3): 19-42.

Ley, D. A. 1980. The effective gm: leader or entrepreneur? The Cornell Hotel and Restaurant Administration Quarterly 21 (3): 66-67.

Liu, D., X.-P. Chen, and X. Yao. 2011. From autonomy to creativity: A multilevel investigation of the mediating role of harmonious passion. Journal of Applied Psychology 96 (2): 294-309.

Maxwell, G. A., and S. Watson. 2006. Perspectives on line managers in human resource management: Hilton international's UK hotels. The International Journal of Human Resource Management 17 (6): 1152-70.

Mayock, P. 2012. Brands vs. Owners: Who knows best? Hotel News Now, April 2. http://www.hotelnewsnow.com/articles.
aspx/7876/Brands-vs-owners-Who-knows-best? (accessed January 24, 2014).

Merchant, K. A. 1981. The design of the corporate budgeting system: Influences on managerial behavior and performance. Accounting Review 56 (4): 813-29.

Mintzberg, H. 1975. The manager's job: Folklore and fact. Harvard Business Review 53 (4): 49-61.

Mongiello, M., and P. Harris. 2006. Management accounting and corporate management: Insights into multinational hotel companies. International Journal of Contemporary Hospitality Management 18 (5): 364-79.

Morey, R. C., and D. A. Dittman. 2003. Evaluating a hotel GM's performance: A case study in benchmarking. The Cornell Hotel and Restaurant Administration Quarterly 44 (5-6): 5359.

Morgeson, F. P., and S. E. Humphrey. 2008. Job and team design: Toward a more integrative conceptualization of work design. In Research in personnel and human resource management, ed. Joseph J. Martocchio, 39-92. Bradford, UK: Emerald Group Publishing.

Morrison, A., and F. Conway. 2007. The status of the small hotel firm. Service Industries Journal 27 (1): 47-58.

Nebel, E. C., and A. Ghei. 1993. A conceptual framework of the hotel general manager's job. Journal of Hospitality \& Tourism Research 16 (3): 27-38.

Nebel, E. C., J.-S. Lee, and B. Vidakovic. 1995. Hotel general manager career paths in the United States. International Journal of Hospitality Management 14 (3): 245-60.

Nolan, C. 2002. Human resource development in the Irish hotel industry: The case of the small firm. Journal of European Industrial Training 26 (2-3-4): 88-99.

Okumus, F., and K. Wong. 2004. A critical review and evaluation of teaching methods of strategic management in tourism and hospitality schools. Journal of Hospitality \& Tourism Education 16 (2): 22-33.

Okumus, F., and K. K. F. Wong. 2005. In pursuit of contemporary content for courses on strategic management in tourism and hospitality schools. International Journal of Hospitality Management 24 (2): 259-79.

Okumus, F., K. K. F. Wong, and L. Altinay. 2009. Are we teaching strategic management right? Journal of Teaching in Travel \& Tourism 8 (4): 329-50.

Olsen, M. D. 1991. Structural changes: The international hospitality industry and firm. International Journal of Contemporary Hospitality Management 3 (4): 21-24.

Olsen, M. D., E. C. Y. Tse, and J. J. West. 2008. Strategic management in the hospitality industry. Upper Saddle River: Pearson Prentice Hall.

O’Neill, J. W. 2000. Strategic directions of hotel industry expectations. Hospitality Review 18 (2): 51-60.

O’Neill, J. W., and M. Carlbäck. 2011. Do brands matter? A comparison of branded and independent hotels' performance during a full economic cycle. International Journal of Hospitality Management 30 (3): 515-21.

O'Neill, J. W., and A. S. Mattila. 2010. Hotel brand strategy. Cornell Hospitality Quarterly 51 (1): 27-34. doi:10.1177/1938965509352286

O'Neill, J. W., and Q. Xiao. 2006. The role of brand affiliation in hotel market value. The Cornell Hotel and Restaurant Administration Quarterly 47 (3): 210-23. 
Phillips, P. A. 2000. The strategic planning/finance interface: Does sophistication really matter? Management Decision 38 (8): 541-49.

Ramanathan, R. 2012. An exploratory study of marketing, physical and people related performance criteria in hotels. International Journal of Contemporary Hospitality Management 24 (1): 44-61.

Randolph, W. A. 2000. Re-thinking empowerment: Why is it so hard to achieve? Organizational Dynamics 29 (2): 94-107.

Raub, S., and C. Robert. 2013. Empowerment, organizational commitment, and voice behavior in the hospitality industry evidence from a multinational sample. Cornell Hospitality Quarterly 54 (2): 136-48.

Ross, G. F. 1997. Career stress responses among hospitality employees. Annals of Tourism Research 24 (1): 41-51.

Ryan, R. M., and E. L. Deci. 2000. Self-determination theory and the facilitation of intrinsic motivation, social development, and well-being. American Psychologist 55 (1): 68-78.

Salazar, J., C. Pfaffenberg, and L. Salazar. 2006. Locus of control vs. employee empowerment and the relationship with hotel managers' job satisfaction. Journal of Human Resources in Hospitality \& Tourism 5 (1): 1-15.

SAS Institute Inc. 2012. JMP, version 10. Cary, NC: SAS Institute Inc.

Schlup, R. 2004. Hotel management agreements: Balancing the interests of owners and operators. Journal of Retail \& Leisure Property 3 (4): 331-42.

Sharma, A. 2008. Strategy models and their application to smalland medium- sized enterprises. In Handbook of hospitality strategic management, ed. Michael D. Olsen and Jinlin Zhao, 425-52. Oxford: Butterworth-Heinemann.

Sharma, A. 1997. Professional as agent: Knowledge asymmetry in agency exchange. Academy of Management Review 22 (3): 758-98.

Sharma, A. 2002. Trends in internet-based business-to-business marketing. Industrial Marketing Management 31 (2): 77-84.

Siemsen, E., A. Roth, and P. Oliveira. 2010. Common method bias in regression models with linear, quadratic, and interaction effects. Organizational Research Methods 13 (3): 45676.

Singh, A. J., R. D. Kline, Q. Ma, and P. Beals. 2012. Evolution of hotel asset management: The historical context and current profile of the profession. Cornell Hospitality Quarterly. doi:10.1177/1938965512458351

Singh, A. J., and R. S. Schmidgall. 2005. Future events and their impact on financial management in the U.S. lodging industry:
Delphi study to predict changes in 2007 and 2027. Journal of Retail \& Leisure Property 4 (3): 236-54.

Slattery, P. 2012. The economic ascent of the hotel business. Oxford: Goodfellow.

Takeuchi, R., J. P. Shay, and J. Li. 2008. When does decision autonomy increase expatriate managers' adjustment? An empirical test. Academy of Management Journal 51 (1): 4560.

Turner, M. J., and C. Guilding. 2010. Hotel management contracts and deficiencies in owner-operator capital expenditure goal congruency. Journal of Hospitality \& Tourism Research 34 (4): 478-511.

Vachani, S. 1991. Distinguishing between related and unrelated international geographic diversification: A comprehensive measure of global diversification. Journal of International Business Studies 22 (2): 307-22.

Way, S. A. 2002. High performance work systems and intermediate indicators of firm performance within the U.S. small business sector. Journal of Management 28 (6): 765-85.

Wiesner, R., J. McDonald, and H. C. Banham. 2007. Australian small and medium sized enterprises (SMEs): A study of high performance management practices. Journal of Management \& Organization 13 (3): 227-48.

Woods, R. H., D. G. Rutherford, R. Schmidgall, and M. Sciarini. 1998. Hotel general managers. The Cornell Hotel and Restaurant Administration Quarterly 39 (6): 38-44.

Woolley, S., Kathleen M., Richard A. M., and S. Anderson. 1997. The new world of real estate. Business Week, September 22, 78-84.

Worsfold, P. 1989. A personality profile of the hotel manager. International Journal of Hospitality Management 8 (1): 51 62.

Yagil, D. 2006. The relationship of service provider power motivation, empowerment and burnout to customer satisfaction. International Journal of Service Industry Management 17 (3): 258-70.

\section{Author Biographies}

Demian Hodari is an Assistant Professor of Strategic Management at Ecole Hôtelière de Lausanne, Switzerland.

Michael C. Sturman is a Professor of Management, the Kenneth and Marjorie Blanchard Professor of Human Resources, and the Associate Dean for Faculty Development at Cornell University's School of Hotel Administration 